\title{
Non-adaptive evolution of the $m$. palmaris longus in the Homininae.
}

Zach Throckmorton*, Nicole Forth, and Nathanial Thomas

Lincoln Memorial University-DeBusk College of Osteopathic Medicine

*Corresponding author: zachary.throckmorton@Imunet.edu

\section{Abstract:}

The palmaris longus muscle is widely recognized for its notable variability in living humans. These variations include not only muscle belly reversal, distinct double muscle bellies, duplication and triplication, but also total uni- or bilateral agenesis (absence). A review of the literature and data novel to this study illustrate that different populations of humans exhibit remarkable variation in the frequency of palmaris longus agenesis, from less than $5 \%$ of Chinese to nearly $65 \%$ of Indians. Comparative dissection-derived data reveal substantial variation in palmaris longus agenesis (PLA) in populations of extant humans (H. sapiens), chimpanzees (Pan spp.), and gorillas (Gorilla spp.) - but not orangutans (Pongo spp.), which apparently always develop this muscle. From this pattern, we infer that palmaris longus is undergoing non-adaptive, stochastic evolution in the extant African Homininae, while it continues to have adaptive purpose in Pongo, likely due to the orangutans' greater degree of arboreality than the African apes and humans. Clinical evidence supports this conclusion, at least as it applies to humans. This study highlights the utility of comparative soft tissue data collection and interpretation in elucidating the evolution of anatomical structures that do not fossilize.

\section{Text:}

Musculus palmaris longus, or simply palmaris longus, is one of the superficial flexor muscles in the antebrachium. It is one of the most variable muscle in the human body, both in its specific form as well as its total agenesis. In humans and in the great apes, this muscle usually arises from the medial epicondyle of the humerus and passes distally, lying medial to the flexor carpi radialis muscle. It continues on to the inferior aspect of the wrist, usually inserting into the flexor retinaculum, and sometimes sending tendinous fibers to the palmar aponerurosis proper. More common variants of palmaris longus include: belly reversal (the muscle belly is located distally rather than proximally), double-belly (both a proximal and a distal muscle belly are present with an intermediate tendon), duplication or triplication (two or three palmaris longus muscles present in one antebrachium), accessory tendinous slips (one palmaris longus muscle that has multiple origins and/or insertions), and agenesis (the palmaris longus muscle is simply absent from the antebrachium, either uni- or bilaterally).

These different variations are potentially clinically relevant as they may cause compartment syndrome (abnormally high pressure in the anterior antebrachial muscle compartment), carpal tunnel syndrome, or Guyon's syndrome (entrapment of the ulnar nerve in Guyon's canal, the space between the pisiform and the hamate's hook). Absence of the palmaris longus muscle has not been shown to significantly affect grip or pinch strength (Sebastin et al. 2005, Ertem et al. 2007). Its tendon is often harvested for grafts, usually for replacement of the flexor pollicis longus tendon (Unglaub et al. 2006). Its use is also documented in the reconstruction of the lower lip in patients with cancer of the lip or gums (Jeng et al. 2004), in formation of a sling to correct ptotic (drooping) eyelids (Lam et al. 1996), and in the repair of chronic, incomplete tears to the ipsilateral triceps tendon (Scolaro et al. 2013). Adverse 
effects suffered by patients resulting from the surgical removal and relocation of their palmaris longus have not been documented. Therefore, its absence likely does not affect fitness in humans.

In primates, PLA is documented in neither prosimians nor monkeys. However, Hominidae PLA is variable. Because the provenience of dissected apes is rarely recorded in the literature, subpopulation distribution of PLA is understood only in humans (Table 1). Some human populations, such as Chinese, exhibit palmaris longus agenesis frequency of less than 5\% (Roohi et al. 2007), while others, such as Indians, have palmaris longus agenesis of nearly 65\% (Ceyhan \& Mavt 1997) - though another study of Indians (Kapoor et al. 2008) reported PLA of less than 20\%, unsurprisingly indicating that a nation of over 1 billion humans exhibits regional variability. A similar pattern is found in the populous nation of Nigeria (Adejuwon et al. 2012, Kayode et al. 2008) Interestingly, both South (Machado \& Di Dio 1967) and North American (Thompson et al. 1921) Natives exhibit low rates of PLA, perhaps owing to their north Asian ancestry. Interestingly, Chilean college students exhibit higher rates of PLA than Native South Americans (Alves et al. 2007), perhaps owing to educational access disparities between Natives and more European-descended people.

There are no systematic, large-sample surveys of muscular variation in the great apes. Reported great ape PLA frequency data are given in Table 2. Though only 13 orangutans are noted for this character in the literature, palmaris longus was present in all 26 of their arms. Of the 61 chimpanzees surveyed and reported by researchers, six exhibited bilateral palmaris longus agenesis and seven exhibited unilateral PLA; that is, approximately one out five of chimpanzees lack palmaris longus in at least one arm. Gorillas exhibit the highest rates of great ape PLA, with 15 of 21 specimens lacking this muscle in one or both antebrachia.

Chimpanzees, gorillas, and humans are less arboreal than orangutans (Tuttle and Watts 1985, Hunt 1990, Remis 1995), with the orangutan retaining the most arboreally-adapted musculoskeletal system of the Hominidae. Reliance upon arboreal quadrumanous locomotion necessitates maintenance of strong wrist flexion facilitated by $m$. palmaris longus in orangutans, which have the relatively longest arms of the Homininae and use their hands in a marked variety of postures (Cant 1987). This selection pressure is diminished in more terrestrial apes and humans; that is, negative selection against individuals lacking palmaris longus is relaxed in the African apes and humans. Released from its role in arboreal locomotion, m. palmaris longus could potentially be undergoing non-adaptive evolution (i.e., drift) in the Homininae. Though our data are not a direct test of this assertion, they are consistent with it. The absence of adverse consequences of surgical removal of palmaris longus in humans suggests the muscle's vestigiliaty, at least in our own species. In vivo electromyographic studies of palmaris longus recruitment in the apes would shed additional light on this issue; the expectation is that the muscle is utilized during typical orangutan arboreal locomotion, but is not important in chimpanzee and gorilla knuckle-walking (and perhaps not recruited when the African apes engage in arboreal behaviors).

While it is tempting to infer that incidence of PLA is a simple linear relationship with each species of Homininae's degree of arboreality, with the most arboreal orangutans retaining the muscle, the most terrestrial gorilla usually lacking it, and the chimpanzee intermediate for both arboreality and incidence of palmaris longus agenesis, the wide range of human subpopulation PLA frequency variation casts doubt on such a simple interpretation of the data. Some human subpopulations exhibit palmaris longus agenesis frequency like chimpanzees, while others more closely match gorillas. Furthermore, the low sample sizes of the great apes compared to the large sample sizes from many human 
subpopulations cautions against great confidence in interpreting the evolutionary history of $m$. palmaris longus in the Homininae. Indeed, regarding soft tissue structures that do not fossilize, large-scale surveys of comparative data provide a useful means for understanding anatomical evolution given the currently insufficient understanding of the genetic and developmental etiologies of most specific anatomical structures.

\section{Acknowledgements:}

We thank the Lincoln Memorial University DeBusk College of Osteopathic Medicine and Anatomical Sciences Master of Science Program for their support of this research. We also thank the donors who generously gave their bodies to anatomical training and study.

\section{References:}

Adejuwon SA, Salawu OT, Ajibola B. 2012. Agenesis of Palmaris Longus Muscle in Selected Population of School Children in Nigeria. International Journal of Morphology. 30(4):1593-1596.

Albay S, Kastamoni Y, Sakalli B, Tunali S. 2013. Anatomy and variations of palmaris longus in fetuses. Rom J Morphol Embryol. 54(1):85-89.

Alves N, Ramírez D, Deana NF. 2011. Study of frequency of the palmaris longus muscle in Chilean subjects. Int. J. Morphol. 29(2):485.

Beddard FE. Contributions to the anatomy of the anthropoid apes. Trans Zool Soc Lond 13:177-218.

Bischoff TLW. 1880. Beitrage zur Anatomie des Gorilla. Abh Bayer Akad Wiss Muenchen Math Phy KI. 13:1-48

Cant, JGH. 1987. Positional behavior of the Bornean orangutan (Pongo pygmaeus). Am J Phys Anthropol. 12:71-90.

Carlson KJ. 2006. Muscle architecture of the common chimpanzee (Pan troglodytes): perspectives for investigating chimpanzee behavior. Primates. 47:218-229.

Ceyhan O, Mavt A. 1997. Distribution of agenesis of palmaris longus muscle in 12 to 18 years old age groups. Indian J Med Sci. 51(5):156.

Champneys F. 1972. The muscles and nerves of a chimpanzee (Troglodytes Niger) and a Cynocephalus Anubis. J Anat Physiol. 6:176-211.

Champman HC. 1879. On the structure of the chimpanzee. Proc Acad Nat Sci Philad. 31:52-63.

Chapman HC. 1880. On the structure of the oran outang. Proc Acad Nat Sci Philad. 32:160-175.

Church WS. 1861. On the myology of the orang outang (Simia morio). Natl Hist Rev 1, 510-516.

Dwight T. 1895. Notes on the dissection and brain of the chimpanzee 'Gumbo'. Mem Boston Soc Nat Hist. 5:31-51. 
Ertem K, Esenkaya I, Elmali N, Yologlu S. 2007. The incidence of missing palmaris longus tendon and its effect on grip and first pinch strengths. Joint Diseases Rel Surg. 18(3):126-129.

Fick R. Vergleichend-anatomische Studien an einem erwachsenen Orang-utang. Arch Anat Physiol Anat Abt. 1895:1-100.

Gratiolet LP, Alix PHE. 1866. Recherches sur l'anatomie du Troglodytes aubryi. Nouv Arch Mus Hist Nat Paris. 2:1-264.

Deniker J. 1885. Recherches anatomiques et emrbyologiques sur les singes anthropoides - foetus de gorille et de gibbon. Arch Zool Exp Gen 3, suppl 3:1-265

Duckworth WLH. Studies from the Anthropological Laboratory, the Anatomy School, Cambridge. London: CJ Clay \& Sons.

Diogo R, Potau JM, Pastor JF, dePaz FJ, Ferrero EM, Bello G, Barbosa M, Wood BA. 2011. Photographic and Descriptive Musculoskeletal Atlas of Gorilla. Enfield: Science Publishers.

Eisler P. 1890. Das Gefaess-und periphere Nervensystem des Gorilla. Talle: Tausch und Grosse.

Erić M, Krivokuća D, Savović S, Lekšan I, Vučinić N. 2010. Prevalence of the palmaris longus through clinical evaluation. Surgical and radiologic anatomy. 32(4):357-361.

Erić M, Koprivčić I, Vučinić N, Radić R, Krivokuća D, Lekšan I, Selthofer R. 2011. Prevalence of the palmaris longus in relation to the hand dominance. Surgical and radiologic anatomy. 33(6):481-484.

Gibbs S. 1999. Comparative soft tissue morphology of the extant Hominoidea, including Man. Unpublished PhD Thesis, The University of Liverpool, Liverpool.

Hartmann R. 1886. Anthropoid Apes. London: Keegan.

Hepburn D. 1892. The comparative anatomy of the muscles and nerves of the superior and inferior extremities of the anthropoid apes, I, Myology of the superior extremity. J Anat Physiol 26:149-186

Hofer G. 1892 Vergleichend-anatomische Studien uber die Nerven des Armes und der Hand bei den Affen und dem Menschen. Munchener Med Abhandl. 30:1-106

Humphry G. 1867. On some points in the anatomy of the chimpanzee. J Anat Physiol. 1:254-268.

Hunt, K. 1990. Positional behavior in Pan troglodytes at the Mahale Mountains and the Gombe Stream National Parks, Tanzania. PhD dissertation, University of Michigan, Ann Arbor.

Hussain FN, Hasan T. 2012. Prevalence of congenital absence of Palmaris Longus tendon in young Jizani population of Saudi Arabia: A cross sectional study.

Jeng SF, Kuo YR, Wei FC, Su CY, Chien CY. 2004. Total lower lip reconstruction with a composite radial forearm-palmaris longus tendon flap: a clinical series. Plast Reconstr Surg. 113(1):19-23. 
Kallner, M. 1956. Die muskulatur und die funktion des schultergurtels und der verderextremitat des orang-utans. Morph Jahrb. 97:554-665.

Kapoor SK, Tiwari A, Kumar A, Bhatia R, Tantuway V, Kapoor S. 2008. Clinical relevance of palmaris longus agenesis: Common anatomical aberration. Anat Science Int. 83:45-48.

Keith A. 1899. On the chimpanzees and their relationship to the gorilla. Proc Zool Soc Lond. 1899:296312.

Kigera JW, Mukwaya S. 2011. Frequency of Agenesis Palmaris Longus through Clinical Examination-An East African Study. PloS ONE. 6(12):e28997.

Lam DS, Lam TP, Chen IN, Tsang GH, Gandhi SR. 1996. Palmaris longus tendon as a new autogenous material for frontalis suspension surgery in adults. Eye. 10(1)38-42.

Loth E. 1931. Anthropologie des parties molles (muscles, intestins, vaisseaux, nerf peripheriques). Paris: Mianowski-Masson et Cie.

Macalister A. The muscular anatomy of the gorilla. Proc Royal Irish Acad, Ser 2. 1:501-506.

MacDowell EC. 1910. Notes on the myology of Anthropopithecus niger and Papio-thoth ibeanus. Am J Anat. 10:431-460.

Machado A, Di Dio LJ. 1967. Frequency of the musculus palmaris longus studied in vivo in some Amazon Indians. Am J Phys Anthropol. 27(1):11-19.

Mbaka GO, Ejiwunmi AB. 2009. Prevalence of palmaris longus absence-a study in the Yoruba population. The Ulster medical journal. 78(2):90.

Michaelis P. Beitrage zur vergleichenden Myologie des Cynocephalus babuin, Simia satyrus, Troglodytes niger. Arch Anat Phys Anat Abt 1:205-256.

Miller RA. 1952. The musculature of Pan paniscus. Am J Anat. 91:182-232.

Ndou R, Gangata H, Mitchell B, Ngcongo T, Louw G. 2010. The frequency of absence of palmaris longus in a South African population of mixed race. Clin Anat. 23(4):437-442.

Oishi M, Ogihara N, Endo H, Asari M. 2008. Muscle architecture of the upper limb in the orangutan. Primates. 49:204-209.

Oluyemi K, Adesanya OA, Odion BI, Ukwenya VO. 2008. Incidence of palmaris longus muscle absence in Nigerian population. Int J Morph. 26(2):305-308.

Owen R. 1868. The Anatomy of Vertebrates. Vol. 3, Mammals. London. Longmans, Green \& Co.

Pai MM, Prabhu LV, Nayak SR, Madhyastha S, Vadgaonkar R, Krishnamurthy A, Kumar A. 2008. The palmaris longus muscle: its anatomic variations and functional morphology. Rom J Morphol Embryol. 49(2):215-17. 
Payne RC. 2001. Musculoskeletal adaptations for climbing in hominoids and their role as exaptations for the acquisition of bipedalism. PhD thesis, University of Liverpool.

Pira A. 1913. Beitraege zuer Anatomie des Gorilla, I, Das Extremitaetenmuskelsystem. Morph Jb. 47:309354.

Preuschoft H. 1965. Muskeln and gelenk der vorderextermitat des gorillas. Morph Jb. 107:99-183.

Primrose A. The anatomy of the orang-outang (Simia satyrus), an account of some of its external characteristics, and the myology of the extremities. Trans Royal Can Inst. 6:507-594.

Raouf HA, Kader GA, Jaradat A, Dharap A, Fadel R, Salem AH. 2013. Frequency of palmaris longus absence and its association with other anatomical variations in the egyptian population. Clin. Anat. 26:572-577.

Raven HC. 1950. Regional anatomy of the gorilla. In: The Anatomy of the Gorilla. Gregory WK, Ed. New York: Columbia University Press.

Remis, M. 1995. Effects of body size and social context on the arboreal activies of lowland gorillas in the Central African Republic. Am J Phys Anthropol. 97:413-433.

Ribbing L, Hermansson K. 1912. Kleinere muskelstudien, I11, die distale extremitatenmuskulatur eines schimpansen, Lunds Universitets. Arsskrift NF Afd 2. 8:1-10.

Roohi SA, Choon-Sian L, Shalimar A, Tan GH, Naicker AS, Rehab M. 2007. A study on the absence of palmaris longus in a multiracial population. Mal Orthop J. 1(1):26-28.

Sarmiento E. 1994. Terrestrial traits in the hands and feet of gorillas. Am Mus Novit. 3091:1-56.

Scolaro JA, Blake MH, Huffman GR. 2013. Triceps tendon reconstruction using ipsilateral palmaris longus autograft in unrecognized chronic tears. Orthopedics. 36(1):e117-20.

Sebastin SJ, Puhaindran ME, Lim AYT, Lim IJ, Bee WH. 2005. The prevalence of absence of the palmaris longus-a study in a Chinese population and a review of the literature. J Hand Surg Br. 30(5):525-527.

Sebastin SJ, Lim AY, Wong H. 2006. Clinical assessment of absence of the palmaris longus and its association with other anatomical anomalies-a Chinese population study. Ann Acad Med Sing. 35(4):249.

Sharma DK, Shukla CK, Sharma V. 2012. Clinical assessment of absence of Palmaris longus muscle and its association with gender, body sides, handedness and other neighboring anomalies in a population of Central India. J Anat Soc India. 61:13-20.

Symington J. Observations on the myology of the gorilla and chimpanzee. Rep Brit Assoc Adv Sci. 59:629-630.

Sommer A. 1907. Das Muskelsystem des Gorilla. Jena Z Naturwiss. 42:181-308. 
Sonntag CF. 1924. On the anatomy, physiology, and pathology of the orang-outan. Proc Zool Soc Lond 24:349-450.

Sonntag CF. 1924. The morphology and evolution of apes and man. London: John Bale Sons and Danielsson, Ltd.

Swindler DR, Wood CD. 1973. An atlas of primate gross anatomy: baboon, chimpanzee and men. Seattle: University of Washington Press.

Thompson JW, McBatts J, Danforth CH. 1921. Hereditary and racial variation in the musculus palmaris longus. Am J Phys Anthropol. 4(2):205-218.

Thompson NW, Mockford BJ, Cran GW. 2001. Absence of the palmaris longus muscle: a population study. Ulster Med J. 70(1):22-24.

Tyson E. 1699. Orang-Outang sive Homo sylvestris, or the anatomy of the pygmie compared to that of a monkey, an ape and a man. London: T. Bennet.

Unglaub F, Bultmann C, Reiter A, Hahn P. 2006. Two-staged reconstruction of the flexor pollicis longus tendon. J Hand Surg Br. 31(4):432-5.

Vrolik W. 1841. Recherches d'anatornie comparé, sur le chimpanzé. Amsterdam: Johannes Miller.

Wilder B. 1862. Contributions to the comparative myology of the chimpanzee. Boston J Nat Hist. 6:352384.

Ziegler AC. 1964. Brachiating adaptations of chimpanzee upper limb musculature. Am J Phys Anthropol. 22:15-32. 
Table 1. Frequencies of palmaris longus agenesis in human subpopulations.

\begin{tabular}{|c|c|c|c|c|c|}
\hline Reference & $\mathrm{N}$ & Bilateral Presence & Unilateral PLA & Bilateral PLA & Ancestry \\
\hline Adejuwon et al. (2012) & 564 & 414 & 73 & 77 & Nigerian \\
\hline Albay et al. (2013) & 58 & 33 & 6 & 19 & Romanian \\
\hline Alves et al. (2011) & 200 & 160 & 22 & 40 & Chilean \\
\hline Ceyhan \& Mavt (1997) & 7000 & 2688 & 1365 & 2947 & Indian \\
\hline Eric et al. (2009) & 800 & 500 & 173 & 127 & Belgium \\
\hline Eric et al. (2011) & 542 & 136 & 288 & 118 & Belgium \\
\hline Ertem et al. (2007) & 365 & 77 & 206 & 82 & Turkish \\
\hline Gangata (2009) & 890 & 877 & 8 & 5 & Zimbabwean \\
\hline Hussain \& Hasan (2012) & 400 & 312 & 67 & 31 & Saudi Arabian \\
\hline Kapoor et al. (2008) & 500 & 414 & 46 & 40 & Indian \\
\hline Kayode et al. (2008) & 600 & 413 & 75 & 112 & Nigerian \\
\hline Kigera \& Mukwaya (2011) & 800 & 766 & 26 & 9 & Ugandan \\
\hline Machado \& Di Dio (1967) & 379 & 365 & 4 & 10 & Native Amazonian \\
\hline Mbaka \& Ejiwunmi (2009) & 600 & 560 & 34 & 6 & Yoruban \\
\hline Ndou et al. (2010) & 201 & 178 & 12 & 11 & Mixed ancestry South African \\
\hline Roohi (2007) & 153 & 144 & 7 & 2 & Chinese \\
\hline Roohi (2007) & 150 & 133 & 12 & 5 & Malay \\
\hline Sebastin et al. (2005) & 418 & 377 & 17 & 24 & Chinese \\
\hline Sebastin \& Lim (2006) & 329 & 314 & 11 & 4 & Chinese \\
\hline Thompson et al. (1921) & 1201 & 908 & 113 & 180 & European-American \\
\hline Thompson et al. (1921) & 318 & 300 & 6 & 12 & African-American \\
\hline Thompson et al. (1921) & 50 & 48 & 1 & 1 & Native American (Shennecock) \\
\hline Thompson et al. (1921) & 101 & 76 & 11 & 14 & Native American (Penobscot) \\
\hline Thompson et al. (1921) & 25 & 22 & 3 & 0 & Japanese \\
\hline Throckmorton et al. (this study) & 81 & 51 & 16 & 14 & European-American \\
\hline
\end{tabular}


bioRxiv preprint doi: https://doi.org/10.1101/015321; this version posted February 17,2015 . The copyright holder for this preprint (which was not certified by peer review) is the author/funder, who has granted bioRxiv a license to display the preprint in perpetuity. It is made available under aCC-BY-NC-ND 4.0 International license.

Table 2. Frequencies of palmaris longus agenesis in great apes.

\begin{tabular}{|c|c|c|c|c|}
\hline Reference & $\mathrm{N}$ & Bilateral Presence & Unilateral PLA & Bilateral PLA \\
\hline \multicolumn{5}{|l|}{ Pongo } \\
\hline Beddard 1893 & 1 & 1 & & \\
\hline Chapman 1880 & 1 & 1 & & \\
\hline Church 1861-1862 & 1 & 1 & & \\
\hline Fick 1895a,b & 1 & 1 & & \\
\hline Hepburn 1892 & 1 & 1 & & \\
\hline Kallner 1956 & 2 & 2 & & \\
\hline Michaelis 1903 & 1 & 1 & & \\
\hline Oishi et al 2008,2009 & 3 & 3 & & \\
\hline Payne 2001 & 3 & 3 & & \\
\hline Primrose 1899,1900 & 1 & 1 & & \\
\hline Sonntag 1924a & 1 & 1 & & \\
\hline Totals: & 16 & 16 & & \\
\hline \multicolumn{5}{|l|}{ Gorilla } \\
\hline Bischoff 1880 & 1 & & & 1 \\
\hline Chapman 1878 & 1 & & & 1 \\
\hline Deniker 1885 & 1 & & & 1 \\
\hline Diogo et al 2011 & 1 & & & 1 \\
\hline Duckworth 1904 & 1 & & & 1 \\
\hline Eisler 1890 & 1 & & & 1 \\
\hline Hartmann 1886 & 1 & & & 1 \\
\hline Hepburn 1892 & 2 & 1 & & 1 \\
\hline Hofer 1892 & 1 & & & 1 \\
\hline Macalister 1873 & 1 & 1 & & \\
\hline Owen 1868 & 1 & 1 & & \\
\hline Pira 1913 & 1 & & & 1 \\
\hline Preuschoft 1965 & 3 & & 1 & 2 \\
\hline Raven 1950 & 1 & 1 & & \\
\hline Sarmiento 1994 & 2 & 2 & & \\
\hline Sommer 1907 & 1 & & & 1 \\
\hline Symington 1889 & 1 & & & 1 \\
\hline Totals: & 21 & 6 & 1 & 12 \\
\hline \multicolumn{5}{|l|}{ Pan } \\
\hline Beddard 1893 & 1 & 1 & & \\
\hline Carlson 2006 & 2 & 1 & 1 & \\
\hline Champman 1879 & 1 & 1 & & \\
\hline Champneys 1972 & 1 & 1 & & \\
\hline Dwight 1895 & 1 & 1 & & \\
\hline Gibbs 1999 & 14 & 8 & 3 & 3 \\
\hline Gratiolet \& Alix 1866 & 1 & 1 & & \\
\hline
\end{tabular}


bioRxiv preprint doi: https://doi.org/10.1101/015321; this version posted February 17,2015 . The copyright holder for this preprint (which was not certified by peer review) is the author/funder, who has granted bioRxiv a license to display the preprint in perpetuity. It is made available under aCC-BY-NC-ND 4.0 International license.

\begin{tabular}{|c|c|c|c|c|}
\hline Hepburn 1892 & 1 & 1 & & \\
\hline Humphry 1867 & 2 & 1 & & \\
\hline Keith 1899 & 6 & 4 & 1 & 1 \\
\hline Loth 1931 & 10 & 9 & 1 & \\
\hline MacDowell 1910 & 1 & 1 & & \\
\hline Miller 1952 & 1 & 1 & & \\
\hline Ribbing 1912 & 1 & 1 & & \\
\hline Sarmiento 1994 & 9 & 7 & 1 & 1 \\
\hline Sonntag 1923 & 1 & 1 & & \\
\hline Sonntag 1924 & 3 & 2 & & 1 \\
\hline Swindler \& Wood 1973 & 1 & 1 & & \\
\hline Tyson 1699 & 1 & 1 & & \\
\hline Vrolik 1841 & 1 & 1 & & \\
\hline Wilder 1862 & 1 & 1 & & \\
\hline Ziegler 1964 & 1 & 1 & & \\
\hline Totals: & 61 & 47 & 7 & 6 \\
\hline
\end{tabular}

